\title{
Phonetic Errors Produced by Students of Speaking 2 of the English Department of Petra Christian University
}

\author{
Oscar Jodi Putra \\ English Department, Faculty of Languages and Literature, Petra Christian University, Siwalankerto 121- \\ 131, Surabaya 60236, INDONESIA \\ E-mail: m11415060@john.petra.ac.id; oscarjodi26@gmail.com
}

\begin{abstract}
This study analyzed phonetic errors found in the students of Speaking 2 of the English Department of Petra Christian University. There were sixteen students taking part in this study. The main theories for this study are from Celce-Murcia, Brinton, \& Goodwin (2004) on the production of English consonants and Moeliono and Dardjowidjojo (2003) on the production of Indonesian consonants. The method used was qualitative approach. The researcher had the students read four short passages to find out the kinds of phonetic errors and interviewed them to find out what factors that might affect their pronunciation, which contains phonetic errors. The findings revealed fourteen deviation patterns found from the four target consonants observed, mainly caused by the non-existence of the target sounds in students' mother tongue. Additionally, the findings also showed that the learners' attitude towards the language was the most important factor influencing their pronunciation level.
\end{abstract}

Keywords: Phonetic, errors, phonetic errors

\section{INTRODUCTION}

Gilakjani (2012) stated that English pronunciation is one of the most difficult skills to acquire and learners should spend a lot of time to improve their pronunciation. Apart from that, good pronunciation leads to learning while bad one leads to great difficulties in language learning. Moreover, Lanteigne (2006) proposed that difficulties in learning English rely on the fact that some of English sounds do not exist in the mother tongue of the learners, thus contributing to phonological errors.

Moeliono and Dardjowidjojo (2003) concluded that there are four non-existent English sounds in Indonesian, that is, $/ \mathrm{v} /, / / /, / \theta /$, and / $/ 3 /$. In addition, Swan and Smith (2014) also stated that these four non-existent English sounds in Indonesian may cause serious problems to Indonesian speakers. Therefore, the writer chose these four consonants to be observed.

In addition, Yostanto (2008) stated that learners tend to generate errors in the articulation of sounds because of the difficulties provided by English pronunciation. The writer chose students of Speaking 2 as the subjects of the study since in Speaking 1, the students learned standard American pronunciation to support communicative tasks (Petra Christian University, 2017). It was a plausible choice due to the students' exposure to the pronunciation rules taught beforehand.

In this study, the researcher wanted to find out the kinds of phonetic errors students produced when they read the short passages as well as factors that may contribute to one's pronunciation, which covers phonetic errors. In answering the research questions, the researchers used two main theories on the production of English consonants from Celce-Murcia et. al. (2004) and of Indonesian consonants from Moeliono and Dardjowidjojo (2003). Celce-Murcia et. al. (2004) and Moeliono and Dardjowidjojo (2003) both mentioned that there are three dimensions that 
distinguish English and Indonesian consonants respectively, that is, voicing, place of articulation, and manner of articulation.

In details, voicing is whether there is a vibration or not in the vocal cords, when there is, the voiced sound is produced, whereas the voiceless sound is produced when there is not. Place of articulation refers to the place where the sound is produced. These are the names of the sounds based on the place of articulation: bilabial, labiodental, dental, alveolar, palatal, velar, and glottal. Finally, the manner of articulation refers to how the airflow is affected and consists of stop, fricatives, affricates, nasal, liquids, and glides.

Moreover, in determining which target consonants to be observed, the researcher compared the English and Indonesian consonants from both of the two theories and came up with and decided four non-existent English consonants in Indonesian, in regards to differences in voicing, places, and manner of articulation. They are $/ \mathrm{v} /, / \mathrm{\delta} /, / \theta /$, and $/ 3 /$. With this, the researcher excluded three sounds from this study, that is, $\mathbf{t} \mathbf{g} /, / \mathbf{d} \mathbf{z} /$, and $/ \mathbf{\mathbf { s }} /$ since these sounds have equivalents in Indonesian despite having different symbols.

In addition, the researcher also used various theories on pronunciation improvement strategies, and factors affecting one's pronunciation gathered from different sources. Some strategies mentioned were minimal pairs, impersonation, and watching YouTube whereas factors affecting pronunciation were language exposure, family support, and attitude towards the language.

\section{METHODS}

In this study, the researcher used a qualitative approach. There were two methods of collecting the data, which were, reading tests and the interviews. In collecting the first data, first, the researcher chose sixteen participants, who were later divided into two groups of A (twelve students who got final grades of A for Speaking 1) and B (four students who got final grades of $\mathrm{B}+, \mathrm{B}, \mathrm{C}+$, and $\mathrm{C}$. The researchers had students read short passages containing the target consonants in target words. There were four short passages (one for each target sound) the participants had to read. These consist of one passage made by the researcher, and the rest were adapted from online sources and modified by the researcher himself. Then, the researcher recorded their pronunciation at the library of Petra Christian University. Later, the phonetic transcriptions were transcribed using a table. Then the results from this table were moved to the analysis table.

\section{Table 1. Deviation Patterns of the Target Sounds}

\begin{tabular}{|c|c|c|c|c|c|c|c|c|c|}
\hline \multirow[t]{2}{*}{ Sound } & \multirow[t]{2}{*}{ Pos. } & \multicolumn{4}{|c|}{ Group A } & \multicolumn{4}{|c|}{ Group B } \\
\hline & & Occ. & $\mathrm{C}$ & $\mathrm{D}$ & Error \% & Occ. & $\mathrm{C}$ & $\mathrm{D}$ & Error \% \\
\hline \multirow[t]{3}{*}{$/ \mathrm{Y} /$} & Initial & B & & & & B & & & \\
\hline & Medial & & & & & & & & \\
\hline & Final & & & & & & & & \\
\hline
\end{tabular}

/Y/ represents the target consonant. B represents how many times the sounds occurred whereas $\mathrm{C}$ and $\mathrm{D}$ represent the actual sounds they pronounced. Pos. refers to positions, that is, how many target words in one position occur in one specific passage. On the other hand, Occ. refers to occurrences. They are results of the multiplication of positions and number of students in a particular group. However, the numbers of occurrences in each table and or each group differ, depending on the number of target words and the number of groups belonging to a certain group.

This table is the sample table for all deviation patterns tables. In total, there are five tables of 
deviation patterns for each of the four target consonants $(/ \mathrm{v} /, / \mathrm{d} /, / \theta /$, and $/ 3 /)$. Only for the sound $13 /$, there are two tables. Error percentages were used to highlight the differences between results in Groups A and B, as well as to prove a theory saying, the higher the proficiency, the least errors students produce (De Zarobe and Catalan, 2009). To count the error percentages for each group, this formula was used. The writer then analyzed all the deviation patterns discovered based on theories on the production of English and Indonesian consonants.

Total number of occurences of the incorrect sounds in one position

Total number of occurences of all sounds in one position

x $100 \%$

For the interviews, the researcher divided those in Group A into A1 \& A2, whereas Group B remained the same. The reason to divide into two subgroups again for Group A was because those in A1 had native-like pronunciation that the writer could hear and pick up since reading tests and had no problems pronouncing at all. On the other hand, those in A2 had good and fine pronunciation, not at the level of their counterparts in A1. Finally, those in Group B were struggling in acquiring correct and proper pronunciation.

The researcher made three separate lists of questions for all the participants in three groups. Questions asked to Groups A1 \& A2 were quite similar despite having different wording whereas questions asked to Group B were significantly different. The researcher recorded their responses at the same place as the reading tests. Before the participants answered the respective questions, the researcher asked them whether they had done the pronunciation improvement strategies, which were, minimal pairs, impersonation, doing accents, watching YouTube, talking to native speakers, and tongue twisters. After collecting all their responses, the researcher summarized and rephrased them into shorter sentences or phrases.

The researcher then ticked or gave cross to the responses, while for the questions, the writer wrote them in bullet points. In analyzing the interview results, the researcher calculated first how many students did each of the pronunciation improvement strategies and consequentially found which strategies were most, never, or rarely used by the students. An overview of the strategies was also given in a table. Table 4 below is the sample table. After completing the table, the researcher discussed briefly why some strategies were used, and the rest were not.

Table 2. Strategies Employed by the Students

\begin{tabular}{|l|l|l|l|l|}
\hline Type of Strategy & Group A1 & Group A2 & Group B & Total \\
\hline Minimal Pairs & & & & \\
\hline Tongue Twisters & & & & \\
\hline
\end{tabular}

In addition to that, the researcher looked for and categorized similar answers. The researcher did this to help him find a pattern that could determine what factors that may contribute to one's pronunciation, which contains phonetic errors. In total, there are four tables for the interview responses. The first three tables contain the responses gathered from the six questions from the students in Groups A1 and A2. One table contains responses from two interview questions. In total, there are responses from all six questions. The last table, however, contains the responses from those in Group B. The reason why the researcher separated the responses from the first two groups and the last group was because the questions asked to students in Group B were significantly different than the questions asked to those in A1 and A2.

The researcher put the similar responses in the left column of the table and put the number and the total number of both groups in the next respective columns for Table 5. For Table 6, the researcher put all the six responses in the left column of the table and put the number of students in the next respective column. Table 3 and 4 are below. 
Table 3. Students' Interview Responses in Groups A1 and A2

\begin{tabular}{|l|l|l|l|}
\hline Responses & Group A1 & Group A2 & Total \\
\hline Self-reading & & & \\
\hline Listening to Music & & & \\
\hline Peer Pressure & & & \\
\hline Teacher Pressure & & & \\
\hline
\end{tabular}

Table 4. Students' Interview Responses in Groups A1 and A2

\begin{tabular}{|l|l|}
\hline Responses & Number of Students \\
\hline Challenges in Learning Pronunciation & \\
\hline Rate of English Pronunciation & \\
\hline
\end{tabular}

After finding the most popular to the least favored strategies as well as categorizing the similar answers in tables, the researcher found similarities and differences in what students in one group did that students in the other groups did not. The factors that might have affected their pronunciation were discovered.

\section{FINDINGS AND DISCUSSION}

After the completion of the reading tests, there are 14 deviation patterns found from the four target consonants, specifically, one deviation pattern of $/ \mathrm{v} /$, three deviation patterns, each for the sounds of $/ \theta / \& / \delta /$, and seven deviation patterns of $/ 3 /$. The main causes of the deviation patterns from the phonetic errors were the non-existence of the target consonants as well as fossilization that happened during the students' language learning process.

Surprisingly, no one in Group B was able to pronounce the target consonants of both $/ \theta / \& / \mathrm{d} /$ correctly despite the fact that some students there could pronounce a more difficult sound of $/ 3 /$. Also, no student in Group B was able to pronounce /v/ correctly, except in the initial position, $/ \theta / \& / \delta /$ in all positions, and $/ 3 /$ in initial and final positions. On the other hand, students in Group A have relatively lower error percentages compared to those of Group B. This shows that students in Group B made more errors than their counterparts in Group A. Here, the researcher presents all deviation patterns in one table.

Table 5. Deviation Patterns of All Consonants

\begin{tabular}{|c|c|c|c|c|c|c|c|c|c|c|c|c|c|}
\hline \multirow{2}{*}{$\begin{array}{l}\text { Target } \\
\text { Cons. } \\
\text { Sounds }\end{array}$} & \multirow{2}{*}{ Pos. } & \multicolumn{6}{|c|}{ Group A } & \multicolumn{6}{|c|}{ Group B } \\
\hline & & Occ & $/ \mathrm{v} /$ & \multicolumn{2}{|c|}{ /f/ } & \multicolumn{2}{|c|}{$\%$} & Occ & $/ \mathrm{v} /$ & \multicolumn{2}{|l|}{ /f/ } & \multicolumn{2}{|c|}{$\%$} \\
\hline \multirow{3}{*}{$/ \mathrm{v} /$} & initial & 36 & 6 & \multicolumn{2}{|c|}{30} & \multicolumn{2}{|c|}{83} & 12 & 1 & \multicolumn{2}{|l|}{11} & \multicolumn{2}{|c|}{92} \\
\hline & medial & 36 & 9 & \multicolumn{2}{|c|}{27} & \multicolumn{2}{|c|}{75} & 12 & - & \multicolumn{2}{|l|}{12} & \multicolumn{2}{|c|}{100} \\
\hline & final & 36 & 5 & \multicolumn{2}{|c|}{31} & \multicolumn{2}{|c|}{86} & 12 & - & \multicolumn{2}{|l|}{12} & \multicolumn{2}{|c|}{100} \\
\hline \multirow{4}{*}{ / $\theta /$} & Pos. & Occ & $/ \theta /$ & $/ \mathrm{t} /$ & $/ \mathrm{s} /$ & $\mathrm{X}$ & $\%$ & Occ & $/ \theta /$ & $/ \mathrm{t} /$ & $/ \mathrm{s} /$ & $X$ & $\%$ \\
\hline & initial & 72 & 40 & 32 & - & - & 44 & 24 & & 24 & & - & 100 \\
\hline & medial & 72 & 22 & 49 & 1 & - & 69 & 24 & & 24 & & - & 100 \\
\hline & final & 72 & 31 & 36 & - & 5 & 57 & 24 & & 20 & & 4 & 100 \\
\hline /ठ/ & Pos. & Occ & /ð/ & $/ \mathrm{d} /$ & $/ \theta /$ & $/ \mathrm{t} /$ & $\%$ & Occ & /ð/ & $/ \mathrm{d} /$ & $/ \theta /$ & $/ \mathrm{t} /$ & $\%$ \\
\hline
\end{tabular}




\begin{tabular}{|c|c|c|c|c|c|c|c|c|c|c|c|c|c|c|}
\hline & initial & 72 & 8 & 63 & - & 1 & 89 & \multicolumn{3}{|c|}{24} & 21 & - & 3 & 100 \\
\hline & medial & 72 & 20 & 41 & 6 & 5 & 72 & \multicolumn{2}{|c|}{24} & & 22 & - & 2 & 100 \\
\hline & final & 72 & - & - & 36 & 36 & 100 & \multicolumn{2}{|c|}{24} & & 1 & 1 & 23 & 100 \\
\hline \multicolumn{15}{|c|}{ Group A } \\
\hline \multirow{4}{*}{ /3/ } & Pos. & Occ & $\mid 3 /$ & $/ \mathrm{d}_{3} /$ & $/ \mathrm{tJ}$ & /J & & & $|z|$ & $/ \mathrm{k} /$ & & $/ \mathrm{f} /$ & $\%$ & \\
\hline & initial & 60 & 2 & 22 & 10 & - & & & 23 & - & & & 97 & \\
\hline & medial & 60 & 15 & - & - & 3 & & & 8 & - & & & $\overline{75}$ & \\
\hline & final & 60 & 14 & 5 & 30 & 1 & & & - & 9 & & & 77 & \\
\hline \multicolumn{15}{|c|}{ Group B } \\
\hline \multirow{4}{*}{$\mid 3 /$} & Pos. & Occ & $\mid 3 /$ & $/ \mathrm{d} 3 /$ & $/ \mathrm{t} J$ & /J & & & $\mid \mathrm{z} /$ & $/ \mathrm{k} /$ & & $/ \mathrm{f} /$ & $\%$ & \\
\hline & initial & 20 & - & 8 & - & - & & & 8 & - & & - & 10 & \\
\hline & medial & 20 & 5 & - & - & 9 & & & - & - & & - & 75 & \\
\hline & final & 20 & - & - & 17 & - & & & - & 2 & & 1 & 10 & \\
\hline
\end{tabular}

The sound /v/ was pronounced either as /v/ or /f/. The reason why deviation to /f/ occurred was because of the fact that the sound of $/ \mathrm{v} /$ does not exist in Indonesian. Therefore, / $/$, which is a voiced labiodental fricative, is likely to be pronounced as /f/, which is a voiceless labiodental fricative, being the closest sound the students could pronounce.

There are three kinds of deviations discovered for the sound $/ \theta /$ : deviations to $/ \mathrm{t} / \mathrm{s} / \mathrm{s} /$, and the omission of the target sound, respectively. The deviation of $/ \theta /$ to $/ \mathrm{t} /$ was found the most. Most Indonesians would probably reduce the sound quality of $/ \theta /$ to $/ t /$, which is a voiceless alveolar stop, perceived as the closest relative to $/ \theta /$.

The omission of the sound $/ \theta /$ (represented by a consonant $\mathrm{X}$ ) and the deviation to /s/ were also spotted in the data. Omission is a process where speakers leave or delete a phoneme out of pronunciation as an attempt to fasten and get rid of difficulties in speech. Usually, it occurs before the sonorant consonants, giving the consonants an opportunity to be syllabic so they will occupy the peak of the syllable (Febriyanti, 2015). Deviation to /s/ was found in the word "birthday", /b3rodes/ into /b3rsder/. This might be caused due to a process, that is, fossilization.

For the sound /ð/, /d/, being a voiced alveolar stop, is perceived as the closest consonant to /ð/, being a voiced dental fricative sound for Indonesian speakers. Majority of the words were pronounced as /d/. Students in Group A tend to pronounce a more difficult sound than their counterparts in Group B. Those in A produced more $/ \theta /$ sounds as opposed to those in Group B, who produced $/ \mathrm{t} /$.

The last sound $/ 3 /$ proved to be the most difficult sound as it has the most deviation patterns, in total, seven. / // was the most occurring deviation since it was perceived as the closest sound to the Indonesian speakers. The rest of the sounds were the results of fossilization and native or other-foreign language influence. One of the examples is in the word of "Zhu", pronounced as $/ \mathrm{t} /$ due to probably Chinese-language influence.

From the interview results, there are several tables. The first table deals with strategies whereas the others deal with the interview results. After presenting the tables, the researcher found factors affecting one's pronunciation, which contains phonetic errors. 
Table 6. Strategies Employed by the Participants

\begin{tabular}{|l|l|l|l|l|}
\hline Type of Strategy & Group A1 & Group A2 & Group B & Total \\
\hline $\begin{array}{l}\text { Watching } \\
\text { YouTube }\end{array}$ & 3 & 9 & 3 & $\mathbf{1 5}$ \\
\hline $\begin{array}{l}\text { Talking to } \\
\text { Native speakers }\end{array}$ & 3 & 9 & 3 & $\mathbf{1 5}$ \\
\hline Tongue Twisters & 3 & 9 & 2 & 14 \\
\hline Impersonation & 2 & 8 & 4 & 14 \\
\hline Doing Accents & 3 & 2 & 2 & 7 \\
\hline Minimal Pairs & - & 1 & - & $\mathbf{1}$ \\
\hline
\end{tabular}

From Table 7, the most popular pronunciation improvement strategies were watching YouTube and talking to native speakers with 15 participants doing it out of 16 whereas the least popular is doing minimal pairs.

Asked on how they acquired good pronunciation (Table 7), a total of 8 students mentioned that watching YouTube, TV series, drama as the way they have acquired and improved their pronunciation. The less popular ways are self-reading, acting/drama, and talking to a family member in English.

To possess great skills in pronunciation, all students in Group A1 concurred that learning English since a very young age seriously has contributed significantly to their abilities while also mentioning that in order to develop the language they are acquiring, one has to love the language genuinely as well as enjoying the language. Even though there was only one student in Group A1 who said that, the writer believed that the rest of Group A1 also genuinely love the language, given their English pronunciation abilities.

Table 7. How Students Acquired Good Pronunciation and Their Hobbies

\begin{tabular}{|l|l|l|l|}
\hline Responses & Group A1 & Group A2 & Total \\
\hline $\begin{array}{l}\text { Started since a very } \\
\text { young age }\end{array}$ & 3 & - & 3 \\
\hline $\begin{array}{l}\text { Genuinely love the } \\
\text { language }\end{array}$ & 1 & - & 1 \\
\hline $\begin{array}{l}\text { Watching YouTube, } \\
\text { listening to music }\end{array}$ & 3 & 5 & $\mathbf{8}$ \\
\hline Writing & 2 & - & 2 \\
\hline Self-reading & 1 & - & 1 \\
\hline Online games & - & 2 & 2 \\
\hline Acting/drama & - & 1 & 1 \\
\hline $\begin{array}{l}\text { Talking to A Family } \\
\text { Member in English }\end{array}$ & - & 1 & 1 \\
\hline
\end{tabular}

The fact that students in A1 have been learning English since a very young age is not questionable. Interestingly enough, 2 students mentioned that online games helped them learn and improve pronunciation. The reason why they said so was because through online games, they were able to interact with fellow gamers from around the world using English. On the other hand, 9 students mentioned having or experiencing teachers' pressure directed towards them. Teacher pressure here means students feeling the teacher might have forced them into doing something they could no or thought not necessary in learning. It also refers to the expectations teachers had for them. Meanwhile, only three students admitted that the ones that made them under pressure were their peers. Peer pressure here refers to their friends who exceled in classes better than them, and when they could not be like them, they would be laughed at. 
From Group B, One thing that is easily noticeable is that all students in this group gave relatively low scores that reflect their pronunciation (only ranging from 5-6). All students in this group concurred that they had had problems understanding their lecturers when in class. Some students even said that they are afraid they are not getting a lot from the teachers.

Table 8. Overview of Responses of Group B Students

\begin{tabular}{|l|l|}
\hline Responses & Number of Students \\
\hline $\begin{array}{l}\text { Challenges in Learning Pronunciation } \\
\text { a. New Words } \quad \text { Word Stress }\end{array}$ & 1 \\
b. $\quad \mathbf{3}$ \\
\hline $\begin{array}{l}\text { The Rates of English Pronunciation } \\
5\end{array}$ & 1 \\
6 & $\mathbf{3}$ \\
\hline $\begin{array}{l}\text { Lecturers Teach in A Way They Cannot } \\
\text { Understand }\end{array}$ & $\mathbf{4}$ \\
\hline $\begin{array}{l}\text { Support/Help from Teachers/Friends } \\
\text { a. Asking Friends for Help } \quad \text { Asking Friends but Friend Did Not } \\
\text { b. }\end{array}$ & $\mathbf{3}$ \\
Respond & 1 \\
\hline $\begin{array}{l}\text { English Exposure Since Elementary } \\
\text { School }\end{array}$ & $\mathbf{4}$ \\
\hline Family Support & $\mathbf{4}$ \\
\hline
\end{tabular}

Majority of the students said that their hardest challenge in learning pronunciation came from understanding word stress. Despite having supportive families, it does not translate to their pronunciation abilities. Also, the fact that they have learned English for a long time is not a guarantee to them, since they started taking English seriously up until either high school or college. Having discussed all this, the researcher was able to come up with factors affecting their pronunciation.

In Group A1, first, is the attitude towards the language is seen as an important factor in their pronunciation mastery. It is seen that they use English more often than Indonesian on a daily basis. Language exposure-wise, the fact that they have been learning English since childhood has contributed to their pronunciation mastery as well. Also, language exposure in international school has been influential in their language learning. In addition to the attitude and language exposure, one outstanding factor is the peer pressure. Students in this group are expected to perform better in pronunciation by sounding like native speakers in daily conversations. Also, they understand better the importance of delivering correct stresses and intonation when speaking English. One of the hobbies is doing self-talking and self-reading. They somehow have internalized their hobbies or interests subconsciously as parts of their daily activities.

In Group A2, students have no big issues in pronunciation. The first factor is not going to international school. Secondly, the expectations have made them improve their pronunciation, but the expectations directed towards them tend to be a burden for them as opposed to those in Group A1. Hobbies are the last factor. Students in A2 tend to have more generic hobbies compared to the previous group. Their hobbies include things like watching TV series, singing, playing online games, talking with fellow gamers on online chat room, and reading stories. Most people have these kinds of hobbies. In contrast, those in Group A1 have uncommon hobbies, like self-talking. These uncommon hobbies require extra willingness.

In the last group, there are many important factors that contributed to their current pronunciation 
level. The most important factor that contributes to their pronunciation is their self-reflection on their pronunciation. Students said that they are afraid of making mistakes, shy, and need to learn and find out more about pronunciation. Second are the challenges in learning pronunciation. They mentioned things like lots of different and new words and different ways of pronouncing words (intonation and stressing patterns). Third factor is their teachers' ways of teaching pronunciation. Another factor is their unwillingness to ask for help. Students said they asked for help but their friends never really helped them, but, on the other hand, they never asked their friends' help again. This shows that students in this group do not have full commitment to learning.

In conclusion, students in A1 have developed the love for the language, making English as an important and intrinsic part in themselves, while those in $\mathrm{A} 2$ do not possess pronunciation as good as their counterparts in A1, but are doing fine in terms of pronunciation. On the contrary, for students belonging to Group B, they are struggling and have to do a lot to catch up more. They are still far from reaching the stage where their counterparts in both previous groups are at right now.

\section{CONCLUSION}

This study has found out that the non-existence of the target consonants played a major part in students' production of phonetic errors as well as a phenomenon called fossilization. Also, students who possessed higher proficiency tended to produce more difficult sounds than those who possessed lower proficiency. Finally, attitude towards the language is a primary factor in students achieving the correct pronunciation, as it shows their proficiency as well.

For further research, the researcher also hopes that there is more research on the non-existence of English sounds in students' mother tongue, in which this study focuses on Indonesian mother tongue. Moreover, fossilization is seen as one of the main factors of the production of phonetic errors. As long as he phonetic errors do not cause misunderstanding, it is simply fine. However, if it causes misunderstanding, it still proves that pronunciation teaching and classes are still significantly important. Giving more time for students to practice the non-existent consonants can help students achieve native-like English pronunciation.

Finally, the researcher hopes there is a further research on the influence of World Englishes on one's pronunciation. Acquiring or getting influenced by other non-native English accents is not entirely wrong, but doing so can cause learners to acquire bad pronunciation. It is because in certain accents, learners hear English words that in those accents are fine, but not in the native English accents. These kinds of similar research will contribute to the fields of linguistics in general, and especially phonology.

\section{REFERENCES}

Celce-Murcia, M., Brinton, D., \& Goodwin, J. (2004). Teaching Pronunciation: A Reference for Teachers of English to Speakers of Other Languages. Cambridge: Cambridge University Press.

De Zarobe, Y., \& Catalan, R. M. (2009). Content and Language Integrated Learning: Evidence from Research in Europe. Multilingual Matters. Retrieved November 12, 2018 from http://bit.ly/2Bh31PF

Febriyanti, D. (2015). Assimilation, Reduction and Elision Reflected in the Selected Song Lyrics of Avenged Sevenfold. Sanata Dharma University, 15(1), 2. Retrieved March 10, 2019 from http://e-journal.usd.ac.id/index.php/JOLL/article/download/369/316 
Gilakjani, A. (2012). The Significance of Pronunciationi in English Language Teaching. International Journal of Research in English Education, 1-5. Retrieved December 10, 2018 from https://bit.ly/2SrcPnf

Lanteigne, B. (2006). Common, Persistent Errors in English by Brazilian Portuguese Speakers. TEFL Web Journal, 4(1). Retrieved October 15, 2018, from www.academia.edu/761700/Common_persistent_errors_in_English_by_Brazilian_Port uguese_speakers

Moeliono, A., \& Dardjowidjojo, S. (2003). Tata Bahasa Baku Bahasa Indonesia (3rd ed.). Jakarta: Balai Pustaka.

Petra Christian University. (2017). 2017-2018 English Department catalog. Petra Christian University. Retrieved November 11, 2018, from inggris.petra.ac.id/data/uploads/UP1114-15014942071501494207.pdf

Swan, M., \& Smith, B. (2014). Learner English: A Teacher's Guide to Interference and other Problems (2nd ed.). Cambridge: Cambridge University Press.

Yostanto, A. (2008). A Study of English Phonological Errors Produced by English Department Students of Petra Christian University. Retrieved November 11, 2018, from Online Catalog Petra Christian University: dewey.petra.ac.id/catalog/digital/detail?id=7696 